\title{
Aplikasi Interaktif Materi Pembelajaran Perkembangan Janin dan Persalinan pada SMK Kesehatan Mutiara Insani
}

\author{
Nurdiana Handayani ${ }^{1}$, Angga Aditya Permana ${ }^{2}$ \\ ${ }^{1,2}$ Teknik Informatika, Fakultas Teknik, Universitas Muhammadiyah Tangerang \\ Jl. Perintis Kemerdekaan I No.33, Babakan, Kec. Tangerang, Kota Tangerang, Banten 15118 \\ Penulis untuk Korespondensi/E-mail: dieyan3@gmail.com
}

\begin{abstract}
Abstrak - Komunikasi adalah aktifitas menyampaikan apa yang ada dipikiran, konsep yang kita miliki yang ingin kita sampaikan pada orang lain atau sebagai seni mempengaruhi orang lain untuk memperoleh apa yang kita inginkan. Berbagai metode telah diterapkan untuk mencapai hasil pembelajaran yang maksimal. Namun banyak guru/dosen yang menggunakan metode pembelajaran dengan lisan saja. Hal ini membuat para pelajar jenuh dan bosan. Bahkan sering terjadi dalam Kegiatan Belajar Mengajar (KBM) seorang guru/dosen sulit menjelaskan materi ajar kepada murid-muridnya, karena keterbasan dalam menggambarkan (visualisasi) permasalahan atau materi yang sedang disampaikan. Sebaliknya tidak jarang siswa/mahasiswa yang kreatif ingin membuat sendiri gambaran secara visual materi ajar yang ia terima dari dosen/guru. Untuk mengatasi masalah tersebut, penulis membuat suatu aplikasi berupa aplikasiinteraktif/multimedia interaktif yang tujuannya untuk meningkatkan motivasi belajar melalui pengembangan dan penciptaan sarana belajar, sumber belajar, dan menunjukkan kemajuan teknologi informasi. Aplikasi interaktif ini menggunakan metode perancangan sistem Finite State Machine (FSM) sebagai sebuah metodologi perancangan sistem kontrol, penerapan FSM telah banyak diterapkan pada perangkat lunak.
\end{abstract}

\section{Kata Kunci - Aplikasi, Animasi Interaktif, Finite State Machine (FSM)}

Abstract - Communication is an activity of delivered of the things that contains in our mind, some kinds of concepts that we have and we wanted to deliver it to the others or as an art of influencing the other to do what we want to do. Many methods have been carried out to reach the good result of learning process. Though many teachers/lecturers that only use the learning method orally. This made the students to be bored. There are many cases in the Learning Process that a teacher/lecturer usually faced difficulties in delivering the material to the students, because of its limitation in visualizing the problems or the material that given to the students. On the contrary, there are creative students that often wanted to make their own description visually from the material that he/she got from the teacher/lecturer.To counter and to solve that problems, the writer made a new application called interactive application/interactive multimedia in order to improve their motivation in learning through developing and creating the facilities of learning, the source of learning and showing some progress in information technolog. This interactive application uses the Finite State Machine (FSM) system design methodology as a control system design methodology, the application of FSM has been widely applied to the software.

Keywords - Application, Interactive Animation, Finite State Machine (FSM) 


\section{PENDAHULUAN}

\section{Latar Belakang Masalah}

Komunikasi adalah aktifitas menyampaikan apa yang ada dipikiran, konsep yang kita miliki yang ingin kita sampaikan pada orang lain atau sebagai seni mempengaruhi orang lain untuk memperoleh apa yang kita inginkan. Komunikasi adalah salah satu hal vital dalam dunia pendidikan. Bagaimana mungkin mendidik manusia tanpa berkomunikasi, mengajar orang tanpa berkomunikasi, atau memberi kuliah tanpa bicara. Dengan komunikasi yang efektif, maka transfer ilmu dan nilai bisa berjalan efektif pula. Begitu juga sebaliknya, jika komunikasi tidak efektif, maka transfer ilmu dan nilai pun tidak akan optimal. Dampak yang terjadi misalnya siswa lambat dalam memahami pelajaran. Siswa salah mengintrepasikan maksud dari guru sehingga yang dia pahami justru hal yang salah. Berdasarkan penelitian De porter, manusia dapat menyerap suatu materi sebanyak $70 \%$ dari apa yang dikerjakan, $50 \%$ dari apa yang didengar dan dilihat (audio visual), sedangkan dari yang dilihatnya hanya $30 \%$, dari yang didengarnya hanya $20 \%$, dan dari yang dibacanya hanya $10 \%$. Berdasarkan penelitian tersebut, maka experiental learning harus tetap diutamakan, namun, adakalanya Kegiatan Belajar Mengajar (KBM) dihadapkan pada materi yang tidak dapat dilakukan eksperimenya. Misalnya suatu percobaan membutuhkan waktu terlalu lama atau terlalu mahal. Pada saat inilah diperlukan alat bantu pengajaran, salah satunya adalah pembelajaran menggunakan animasi interaktif.

Guru pun kesulitan menjelaskan materi-materi yang berhubungan dengan gerak, warna, grafik, proses, skala dll. Contoh kecil saja misalnya, siswa mempelajari anatomi tubuh manusia, perkembangan janin, gaya gravitasi bumi dan lain-lain, tedapat kendala jika kita ingin mempraktikannya di laboratorium namun dengan perkembangan teknologi, kesulitan penyampaian materi ajar bisa diatasi. Jika kita perhatikan materi-materi tersebut lebih mudah disampaikan melalui animasi dan simulasi. Model pembelajaran multimedia interaktif ini sangat efektif. Hal tersebut bisa dilihat karena banyaknya unsur visualisasi dan efek dari sound yang ditampilkan. Para guru dapat bekerjasama dengan berbagai pihak untuk menyediakan media pembelajaran ini. Guru sendiri dapat mempelajari berbagai software untuk membuat media pembelajaran yang disesuaikan dengan kebutuhan para siswanya. Salah satu software yang dapat membuat berbagai media seperti video, animasi, gambar, suara, dan sebagainya dengan cara yang mudah adalah Macromedia Flash MX. Software tersebut merupakan program grafis multimedia dan animasi yang dapat dipergunakan untuk membuat aplikasi animasi dan web interaktif yang sangat menarik.

\section{Identifikasi Masalah}

Metode yang ditempuh penulis didalam penelitian guna mengumpulkan data dan informasi sebagai materi yaitu: Analisis dengan menganalisa permasalahan yang terjadi untuk dapat menemukan jawaban apa penyebab masalah-masalah yang timbul. Kegiatan yang dilakukan dalam tahap ini antara lain: Mendeteksi Masalah (Problem Detection) dengan menganalisis dalam sejumlah bagian atau submasalah yang dapat dirumuskan dalam bentuk kalimat pernyataan atau pertanyaan; Investigasi Awal (Initial Investigation) berupa upaya penelitian, penyelidikan, pengusutan, pencarian, pemeriksaan dan pengumpulan data, informasi, dan temuan lainnya untuk mengetahui/membuktikan kebenaran atau bahkan kesalahan sebuah fakta yang kemudian menyajikan kesimpulan atas rangkaian temuan dan susunan kejadian; Analisa Kebutuhan (Requirement Analysis) merupakan suatu proses untuk apa yang seharusnya (sasaransasaran) dan mengukur jumlah ketimpangan antara apa yang seharusnya dengan apa yang senyatanya.

Pengumpulan Data yang dilakukan menggunakan beberapa metode penelitian diantaranya: Metode Observasi (Observation Method) yaitu metode yang mengumpulkan data dengan cara melakukan pengamatan langsung pada objek yang diteliti dan mencatat kejadian-kejadian yang terjadi pada tempat riset atau tempat paktek kerja lapangan; Metode Wawancara (Interview Method) dengan melakukan tanya jawab terhadap pihak yang terkait dengan masalah yang ada dalam penulisan tugas akhir ini untuk mendapatkan kelengkapan data yang lebih terinci tentang segala sesuatu yang berhubungan dengan topik yang dibahas dalam tugas akhir ini; Metode Studi Kepustakaan (Library Study Method) melalui referensi mengenai teori dan konsep 
penunjang penyusunan penelitianini didapatkan melalui buku-buku komputer, artikel-artikel dari internet dan beberapa situs website.

Pembuatan Aplikasi dengan memperhatikan hal sebagai berikut: Perancangan aplikasi dengan tampilan yang interaktif dan dinamis; Aplikasi yang pada waktu-waktu tertentu dapat di update. Testing Aplikasi yaitu sebelum aplikasi yang telah dirancang tersebut digunakan dan diterapkan dalam pembelajaran, harus diuji coba untuk dilakukan tes dan uji coba sehingga akan sesuai dengan keinginan atau kebutuhan dan menghindari kesalahan-kesalahan yang tidak diinginkan

\section{Tujuan dan Manfaat Penelitian}

Tujuan dari peneletian ini adalah untuk mempermudah penyampaian materi pembelajaran terhadap siswa dan memberikan solusi alternatif untuk memudahkan pembelajaran karena keterbatasan dalam menggambarkan (visualisasi).

Manfaat yang diperoleh dari hasil penelitian ini adalah membantu siswa/siswi dalam memahami materi yang sulit dipahami karena perlunya visualisasi dan membantu Guru dalam menyampaikan materi yang sulit disampaikan karena perlunya visualisasi agar siswa/siswi lebih paham.

\section{Ruang Lingkup}

Dalam pembatasan masalah penulisan penelitian penulis berusaha memberikan gambaran yang jelas dengan menggunakan pembahasan yang memadai. Agar tidak menyimpang dari inti masalah, maka penulis memberikan batasan masalah dan menentukan pokok masalah, perumusan masalah merupakan upaya guna mencari jawaban terhadap pertanyaan-pertanyaan yang timbul serta masalah yang hendak dipecahkan.Untuk pembahasan sebuah topik penelitian agar lebih terarah dan terfokus pada tujuan yang ingin dicapai, maka penelitian ini akan membahas mengenai visualisai pada perkembangan janian dan persalinan, dilengkapi dengan tutorial pembuatannya.

\section{LANDASAN TEORI}

Menurut Samodra (2009) dalam jurnalnya yang berjudul "Multimedia pembelajaran Reproduksi pada Manusia", mereka berpendapat bahwa pembelajaran yang baik dapat ditujang dari suasana pembelajaran yang kondusif serta hubungan komunikasi anata guru, siswa dapat berjalan dengan baik [1]. Menurut McAndrews et all dalam jurnalnya yang berjudul "Testing the efficacy Of Reverse Learning as a Teaching And Learning Method Using An Interactive Multimedia Computer Program" [2]. Mereka berpendapat bahwa grade kreatifitas tidak dipengaruhi oleh gaya belajar tanpa strategi pembelajaran. Suasana belajar mengajar yang menyenangkan membuat para siswa memusatkan perhatiannya secara penuh pada belajar dan curah perhatiannya pun tinggi. Dengan menggunakan media pembelajaran ini, para siswa akan berfokus pada materi yang disampaikan. Karena banyak visualisasi yang menarik sehingga para siswa tidak akan bosan dalam belajar. Pentingnya media sebagai alat untuk merangsang proses belajar.

\section{Definisi Multimedia}

Multimedia merupakan kombinasi teks, seni, suara, gambar, animasi dan video yang disampaikan dengan komputer atau dimanipulasi secara digital dan dapat disampaikan atau dikontrol secara interaktif (Iwan, 2010) [3].

\section{Komponen Multimedia Teks}

Teks adalah gabungan dari beberapa huruf yang membentuk kata yang nantinya akan membentuk satu kesatuan kalimat. Teks ini berfungsi untuk menyampaikan sebuah informasi kepada para pembacanya sehingga maksud dan tujuan dari para pembaca terpenuhi dengan informasi yang disampaikan melalui teks tersebut. Teks pada bidang komputer biasanya mempunyai format seperti .txt, rtf, doc, dan lain sebagainya.

\section{Gambar}

Gambar (Image) merupakan suatu representasi spatial dari suatu objek, dalam pandangan 2 dimensi atau 3 dimensi. Gambar dapat mewakili ribuan kata dalam mengartikan pandangan seseorang terhadap sesuatu benda atau objek. Perangkat lunak yang biasa dipakai untuk mengolah atau memanipulasi gambar antara lain Paint, Adobe Photoshop, ACDSee, 
dan sebagainya. Format file gambar seperti .BMP, .JPEG/.JPG, .GIF, .PNG dan lain sebagainya.

\begin{abstract}
Animasi
Animasi adalah sebuah proses merekam dan memainkan kembali serangkaian gambar statis untuk mendapatkan sebuah ilusi pergerakkan (Ibis, 2002) [4]. Animasi adalah "ilusion of motion" yang dibuat dari image statis yang ditampilkan secara berurutan. Pada video atau, animasi merancu pada teknik dimana setiap frame dalam film dibuat secara terpisah. Frame bisa dihasilkan film dari komputer, dari fotografi atau dari gambar lukisan. Ketika frame-frame tersebut digabungkan, maka terdapat ilusi perubahan gambar, sesuai dengan teori yang disebut dengan "persistance of vision“.
\end{abstract}

\section{Suara}

Suara adalah fenomena fisik yang dihasilkan oleh getaran benda. Getaran suatu benda yang berupa sinyal analog dengan amplitudo yang berubah secara kontinyu terhadap waktu. Suara/bunyi biasanya merambat melalui udara. Perangkat lunak yang biasanya digunakan antara lain Winamp, RealPlayer, Windows Media Player, KMPlayer, QuickTime, XMMS, ZoomPlaye,JetAudio,SoundForge,dbPowerAm p,MusicMatchJukeBox, dan iTunes. Format file pada suara seperti Advance Audio Coding (.AAC), Waveform Audio (.WAV), Audio Interchange File Format (AIFF), Mpeg Audio Layer 3 (.MP3), Music Instrument Digital Interface (.MID) dan lain sebagainya.

\section{Video}

Video adalah teknologi untuk menangkap, merekam, memproses, mentransmisikan dan menata ulang gambar bergerak. Biasanya menggunakan filmseluloid, sinyal elektronik, atau media digital. Video dangat berkaitan erat dengan "penglihatan dan pendengaran". Perangkat lunak pengolah video antara lain :QuickTime, WindowsMediaPlayer, ZoomPlayer, DivXPro, RealOne Player, Xing Mpeg Player, PowerDVD.Format file pada video seperti ASF (Advance System Format), MOV (QuickTime), MPEG (Motion Expert Group ), DivX, Windows MediaVideo (WMV) dan lain sebagainya.

\section{Pengenalan Finite State Machine (FSM)}

Menurut Setiawan (2006) mengatakan Finite

State Machine (FSM) adalah sebuah metodologi perancangan sistem kontrol yang menggambarkan tingkah laku atau prinsip kerja sistem dengan menggunakan tiga hal berikut: state (keadaan), event (kejadian), dan action (aksi) [5]. Pada satu saat dalam periode waktu yang cukup signifikan, sistem akan berada pada salah satu state yang aktif. Sistem dapat beralih atau bertransisi menuju state lain jika mendapatkan masukan atau event tertentu, baik yang berasal dari perangkat luar atau komponen dalam sistemnya itu sendiri. Berdasarkan sifatnya, metode FSM ini sangat cocok digunakan sebagai basis perancangan perangkat lunak pengendalian yang bersifat reaktif dan real time. Salah satu keuntungan nyata penggunaan FSM adalah relative besar dengan hanya menggunakan sejumlah kecil item state.

\section{MacromediaFlash 8}

\section{Pengenalan MacromediaFlash 8}

Flash merupakan suatu program aplikasi grafis buatan Macromedia. MaromediaFlash 8 adalah aplikasi powerfull yang digunakan untuk menciptakan presentasi, aplikasi dan isi lain yang memungkinkan interaksi dari pemakai, proyek flash dapat meliputi animasi sederhana, isi video, presentasi yang kompleks (Hidayatullah, 2007) [6]. Program Flash terdiri dari beberapa versi, versi terbaru adalah flash 8 . Flash versi sebelumnya antara lain: flash 5, flash MX, dan flash MX 2004. Flash tersedia dalam sejumlah bahasa. Sesuaikan dengan bahasa yang anda kuasai. Ukuran file program Flash kurang-lebih 100 MB. Flash memiliki sejumlah kelebihan.

Beberapa kelebihan Flash antara lain: Animasi dan gambar konsisten dan fleksibel, karena tetap terlihat bagus pada ukuran jendela dan resolusi layar berapapun pada monitor pengguna; Kualitas gambar terjaga. Hal ini disebabkan karena Flash meggunakan teknologi Vector Graphic yang mendeskripsikan gambar memakai garis dan kurva, sehingga ukurannya dapat di ubah sesuai dengan kebutuhan tanpa mengurangi atau mempengaruhi kualitas gambar. Waktu akses animasi atau gambar cepat dibandingkan dengan program pembuatan animasi yang lain seperti animated gifs maupun Java Applet. 
Mampu membuat animasi secara streaming sehingga sebuah movie atau animasi akan langsung dimainkan sekalipun proses loading belum selesai seluruhnya; mampu membuat desain web yang interaktif, mempunyai fasilitas yang lengkap dan fleksibel untuk menunjang para designer web membuat karyanya; mempunyai kemudahan dalam melakukan import video clip dalam banyak pilihan format file; mudah diintegerasikan dengan program Macromedia yang lain, seperti Dreamweaver, Firework, dan Authorware; mampu menganimasi grafis yang rumit dengan sangat cepat, sehingga membuat animasi layar penuh bisa langsung disambung ke situs web; mampu secara otomatis mengerjakan sejumlah frame antara awal dan akhir sebuah urutan animasi, sehingga tidak membutuhkan waktu yang lama untuk membuat berbagai animasi; dapat diintegerasikan dengan script sisi server (server side scripting) seperti CGI, ASP dan PHP untuk membuat aplikasi pangkalan data web; lingkup pemanfaatan luas, selain tersebut diatas, dapat juga dipakai untuk membuat film pendek atau kartun, presentasi, iklan atau web banner, animasi logo, kontrol navigasi dan lain-lain.

\section{Fasilitas Animasi Dasar Flash}

Flash memiliki fasilitas animasi, yaitu fasilitas dimana kita bisa membuat animasi sederhana yang merupakan animasi teratur, atau juga bisa disebut animasi yang pergerakannya telah kita tentukan dari semula. Berikut ini adalah jenisjenis animasi yang ada pada flash: Animasi Frame to Frame adalah jenis animasi yang paling banyak memakan kapasitas memory, karena itu sebisa mungkin animasi jenis ini dihindari; Animasi Motion Tween yang digunakan apabila kita ingin membuat gerakan animasi yang teratur. Motion tween hanya bisa dilakukan jika objek merupakan suatu group atau symbol; Animasi Motion Guide adalah animasi yang mempunyai gerakan sesuai jalur yang kita buat.

Animasi Masking yang berbentuk seperti sinar yang menerangi kegelapan atau seperti kilauan cahaya yang menerangi kaca. Animasi ini pada intinya menampilkan objek yang semula kita sembunyikan; Animasi Motion Tween Rotate adalah jenis animasi yang membuat animasi putaran, baik itu berputar di tempat maupun berputar sambil berjalan; Animasi Motion Shape adalah animasi yang berguna untuk membuat animasi pembentuk atau animasi pemecah. Jika kita ingin mengubah bentuk animasi ini menjadi bentuk animasi yang berbeda dari sebelumnya, bisa menggunakan jenis animasi ini. Dalam membuat animasi motion shape, objek tidak boleh merupakan suatu group atau symbol.

\section{Macromedia Director}

Director adalah software buatan Macromedia (seperti Flash dan Dreamweaver) yang biasa digunakan untuk pembuatan (Hendratman, 2008) [7]: CD Interaktif Profile perusahaan, Profil pribadi atau marketing lain; Edukasi/Pembelajaran; Katalog Produk; Information Kiosk, seperti di Hotel dan tempat wisata; InterfaceDownloadRigtone Ponsel seperti di toko HP; Game 2 dimensi/Puzzle, seperti CD- interaktif anak cerdas, anak pintar, dan lain-lain; Presentasi Seminar/Event; Director mampu mengimport banyak format seperti: Movie format VCD \& AVI dll: MPG/DAT, MOV, VOB, GIF dll; Bitmap: PSD (photoshop), JPG, GIF, PNG (firework) dan lain-lain; Vector: AL (adobellustrator), SWF (Flash); 3 Dimensi: W3D Shockwave3D (truespace\& 3Dstudiomax); Audio: WAV, MP3, MIDI.

Performance dan kemampuan yang baik dalam hal mengelola file multimedia, macromediaDirector memang luar biasa, jika anda sebelumnya pemakai MacromediaFlash, akan terasa kemudahan dan kehandalan macromediaDirector.

\section{METODE PENELITIAN}

\section{Analisa Kebutuhan}

Analisa kebutuhan merupakan tahapan yang penting dalam proses pembuatan aplikasi termasuk dalam pembuatan pembelajaran interaktif. Dalam tahap ini, dilakukan spesifikasi mengenai semua kebutuhan yang diinginkan oleh pemakai mengenai proses pembuatan aplikasi yang dibuat sehingga menjadikan aplikasi terarah dan sesuai dengan kebutuhan, baik pembuat aplikasi maupun pemakai aplikasi. Analisa kebutuhan pengguna dapat dilakukan dengan teknik wawancara atau kuesioner. 


\begin{abstract}
Identifikasi dan Analisa Kebutuhan Pemakai

Mengidentifikasi dan menganalisa kebutuhan pemakai adalah mencari dan mengetahui apa saja yang dibutuhkan oleh user atau pemakai dalam aplikasi yang akan dibuat, sehingga aplikasi yang dibuat sesuai dengan apa yang pengguna inginkan. Aplikasi yang baik adalah aplikasi yang sesuai dengan kebutuhan pemakai dan bisa menyelesaikan masalah yang dialami oleh pemakai.
\end{abstract}

Teknik yang bisa digunakan untuk mengetahui kebutuhan pemakai adalah dengan wawancara atau kuesioner. Setelah mendapatkan data melalui teknik tersebut, kemudian dibuat aplikasi yang sesuai dengan keinginan pemakai.

\section{Analisa Kebutuhan Sistem}

Dalam merancang kebutuhan sistem aplikasi interaktif, harus berpedoman pada karakteristik dan unsur yang terdapat pada aplikasi tersebut, diantaranya: Format Aplikasi berupa aplikasi interaktif materi pembelajaran Perkembangan Janin dan Persalinan ini menggunakan program Macromedia Flash dengan format .swf; Rules/Aturan-aturan yang terdapat pada quis (soal), game teka-teki dan game puzzle. Siswa/mahasiswa diharapkan dapat interaktif terhadap materi yang disampaikan; Policy/Kebijakan yang diharapkan siswa/mahasiswa dapat mengerti materi-materi yang disampaikan baik oleh guru/dosen maupun yang ada di dalam aplikasi tersebut; Scenario yaitu pada saat pertama aplikasi dijalankan, maka menu cover.swf akan tampil. Kemudian langsung masuk kedalam menu utama, swf dan ada 2 tombol untuk melanjutkan. Jadi setelah akhir materi terdapat latihan soal yang harus dikerjakan, guna untuk mengetahui sebatas mana para siswa menyimak aplikasi yang dijalankan; Event/Challenge (Tantangan) yang ada dalam aplikasi ini adalah dengan diberikan permainan Teka-Teki dan puzzle untuk mengetahui sejauhmana siswa/mahasiswa interaktif terhadap aplikasi interaktif ini. Di dalam permainan puzzle, siswa diharapkan dapat meletakkan potonganpotongan gambar dengan benar secepat mungkin karena ada batasan waktu yang diberikan dalam permainan ini.

Decision di dalam aplikasi ini tidak bisa memilih level atau tingkatan. Karena tingkat kesulitan sudah ditetapkan berdasarkan tahapan pembelajaran. Pada Menu game puzzle hanya diberikan batasan waktu untuk menyelesaikan dalam meletakkan potongan gambar sesuai dengan contoh gambarnya; Level merupakan tingkat kesulitan dalam sebuah aplikasi. Tidak ada level tertentu dalam aplikasi interaktif ini, tertapi siswa/mahasiswa harus menjawab/menyelesaikan Quis (soal), game puzzle dan game teka-teki yang ada di dalam aplikasi ini, untuk mengetahui sejauh mana siswa/mahasiswa mengerti materi yang disampaikan; Score Model dalam aplikasi interaktif ini model skornya berupa nilai yang diberikan setelah siswa/mahasiswa mengerjakan Quis (soa-soal), game puzzle dan game teka teki; Indicator berupa indikasi penentuan keberhasilan dalam aplikasi ini yaitu akan muncul pesan dan score/nilai saat siswa/mahasiswa dapat menjawab semua pertanyaan yang ada disoal dengan benar dan mendapatkan nilai melebihi nilai minimal yang telah ditetapkan, begitu sebaliknya; Symbols yang digunakan dalam aplikasi interaktif ini , antara lain (Tabel 1).

Tabel 1. Daftar Simbol

\begin{tabular}{|c|c|}
\hline Simbol & Keterangan \\
\hline Henu Utama & $\begin{array}{l}\text { Digunakan untuk masuk ke dalam } \\
\text { menu utama }\end{array}$ \\
\hline $\boldsymbol{D}_{\text {Keluar }}$ & $\begin{array}{l}\text { Digunakan untuk ke luar dari aplikasi } \\
\text { interaktif }\end{array}$ \\
\hline Perkembangan Janin & $\begin{array}{l}\text { Digunakan untuk masuk ke dalam } \\
\text { menu aplikasi perkembangan janin }\end{array}$ \\
\hline Persalinan & $\begin{array}{l}\text { Digunakan untuk masuk ke dalam } \\
\text { menu aplikasi persalinan }\end{array}$ \\
\hline Video Persalinan & $\begin{array}{l}\text { Digunakan untuk masuk ke dalam } \\
\text { menu aplikasi video persalinan }\end{array}$ \\
\hline 0 & $\begin{array}{l}\text { Digunakan untuk masuk ke dalam } \\
\text { menu aplikasi Quis }\end{array}$ \\
\hline & $\begin{array}{l}\text { Digunakan untuk masuk ke dalam } \\
\text { menu aplikasi Game Teka-Teki }\end{array}$ \\
\hline Game Puzle & $\begin{array}{l}\text { Digunakan untuk masuk ke dalam } \\
\text { menu aplikasi Game Puzzle }\end{array}$ \\
\hline back & $\begin{array}{l}\text { Digunakan untuk kembali ke menu } \\
\text { utama }\end{array}$ \\
\hline Main & $\begin{array}{l}\text { Digunakan untuk memulai permainan } \\
\text { aplikasi pada menu Quis }\end{array}$ \\
\hline Ulang & $\begin{array}{l}\text { Digunakan untuk main kembali } \\
\text { permainan aplikasi/menjawab } \\
\text { pertanyaan pada menu Quis }\end{array}$ \\
\hline
\end{tabular}




\begin{tabular}{|c|c|}
\hline Simbol & Keterangan \\
\hline PLAY & $\begin{array}{l}\text { Digunakan untuk memulai permainan } \\
\text { pada menu game teka-teki. }\end{array}$ \\
\hline OK & $\begin{array}{l}\text { Digunakan untuk menginput kata } \\
\text { pada kolom-kolom kotak di dalam } \\
\text { permainan teka-teki. } \\
\text { Digunakan untuk mengulang } \\
\text { permainan pada menu puzzle }\end{array}$ \\
\hline
\end{tabular}

\section{Perangkat Umum Mendesain dan Membangun Sistem}

Sistem perangkat komputer baik hardware maupun software yang diperlukan dalam pembuatan aplikasi interaktif ini, adalah:

Tabel 2. Spesifikasi Komputer

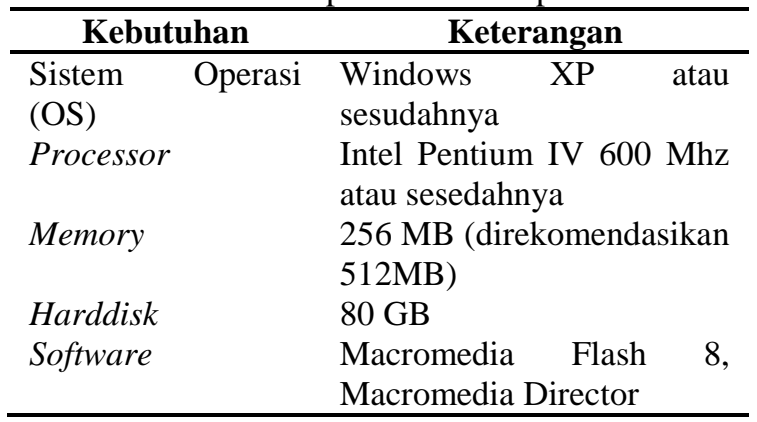

\section{Perancangan (Design)}

Suatu proses perancangan yang sistematis untuk mencipatakan pembelajaran yang efektif dan efesien, serta membuat kegiatan pembelajaran lebih mudah, yang didasarkan pada apa yang kita ketahui tentang teori-teori pembelajaran. Tujuan dari perancangan aplikasi ini adalah untuk membuat spesifikasi secara rinci mengenai arsitektur proyek, gaya dan kebutuhan material untuk proyek.

Dalam bab ini penulis menjelaskan langkahlangkah pembuatan program dengan menggunakan story board dan rancangan interfacenya dengan menggunakan MacromediaFlash MX. Dalam program aplikasi ini membahas mengenai perkembangan janin dari bulan ke bulan hingga terciptanya manusia dan cara persalinan yang alamiah dengan menggunakan gambar animasi dan suara sehingga membuat tampilan lebih menarik.

\section{Perancangan Story Board}

Storyboard merupakan terjemahan berupa gambar cerita naskah yang sudah dibuat, dan digunakan dalam proses perancangan sebuah produk multimedia. Bentuk storyboard bisa bermacam-macam, diantaranya berupa gambar visual, keterangan percakapan, keterangan adegan, keterangan special effect, dan durasi. Selain storyboard, juga dikenal lain dalam menyajikan alur cerita yaitu narasi, skrip dialog, dan skrip skenario. Kelebihan penggunaaan storyboard dibanding dengan teknik-teknik tersebut dalam menyajikan alur cerita adalah bahwa pengaturan secara visual mudah diwujudkan karena sudah terilustrasi melalui gambar.

\section{Perancangan User Interface}

User Interface merupakan mekanisme komunikasi antara pengguna (user) dengan sistem aplikasi interaktif. Digunakan untuk menginput pengetahuan baru ke dalam aplikasi, menampilkan penjelasan system dan memberikan panduan pemakaian aplikasi secara menyeluruh step by step sehingga user mengerti apa yang akan dilakukan terhadap suatu system aplikasi.

\section{Pengujian Sistem dengan Black Box}

Pengujian black box merupakan pengujian yang hanya mengamati hasil eksekusi melalui data uji dan memeriksa fungsional dari perangkat lunak. Tujuannya untuk menunjukkan fungsi perangkat lunak tentang cara operasinya, apakah pemasukan data keluaran telah berjalan sebagaimana yang diharapkan dan apakah informasi yang disimpan secara eksternal selalu dijaga kemutakhirannya.

Keunggulan Black Box, antara lain; Bisa memilih subset test secara efektif dan efesien dapat menemukan cacat dan dapat membantu memaksimalkan testing investment. Kelemahan Black Box, antara lain; terdapat kemungkinan masih ada beberapa jalur eksekusi yang belum pernah diuji oleh tester.

\section{HASIL DAN PEMBAHASAN}

\section{Story Board Menu Opening}

Berikut ini gambaran dari story board Menu Opening seperti yang dijelaskan pada tabel dibawah in 
Tabel 3. Story Board Menu Opening

\begin{tabular}{cl}
\hline $\begin{array}{c}\text { Story } \\
\text { Board }\end{array}$ & \multicolumn{1}{c}{ Keterangan } \\
\hline VISUAL & $\begin{array}{l}\text { Ketika program pertama kali } \\
\text { dijalankan, maka akan muncul menu } \\
\text { opening sebelum masuk ke menu } \\
\text { utama. Di dalam Menu opening } \\
\text { terdapat 2 (dua) pilihan menu yaitu: } \\
\text { Menu Utama dan Keluar. Jika dipilih } \\
\text { tombol Menu Utama maka akan } \\
\text { masuk ke animasi menu utama, dan } \\
\text { jika pilih tombol Keluar maka keluar } \\
\text { dari aplikasi interaktif tersebut. } \\
\text { Materi Pembelajaran } \\
\text { SKETSA } \\
\text { Perkembangan Janin \& Persalinan } \\
\text { SMK Kesehatan }\end{array}$ \\
Menu Utama \\
\hline
\end{tabular}

\section{Story Board Menu Utama}

Gambaran dari story board Menu Utama seperti yang dijelaskan pada tabel dibawah ini:

Tabel 4. Story Board Menu Utama

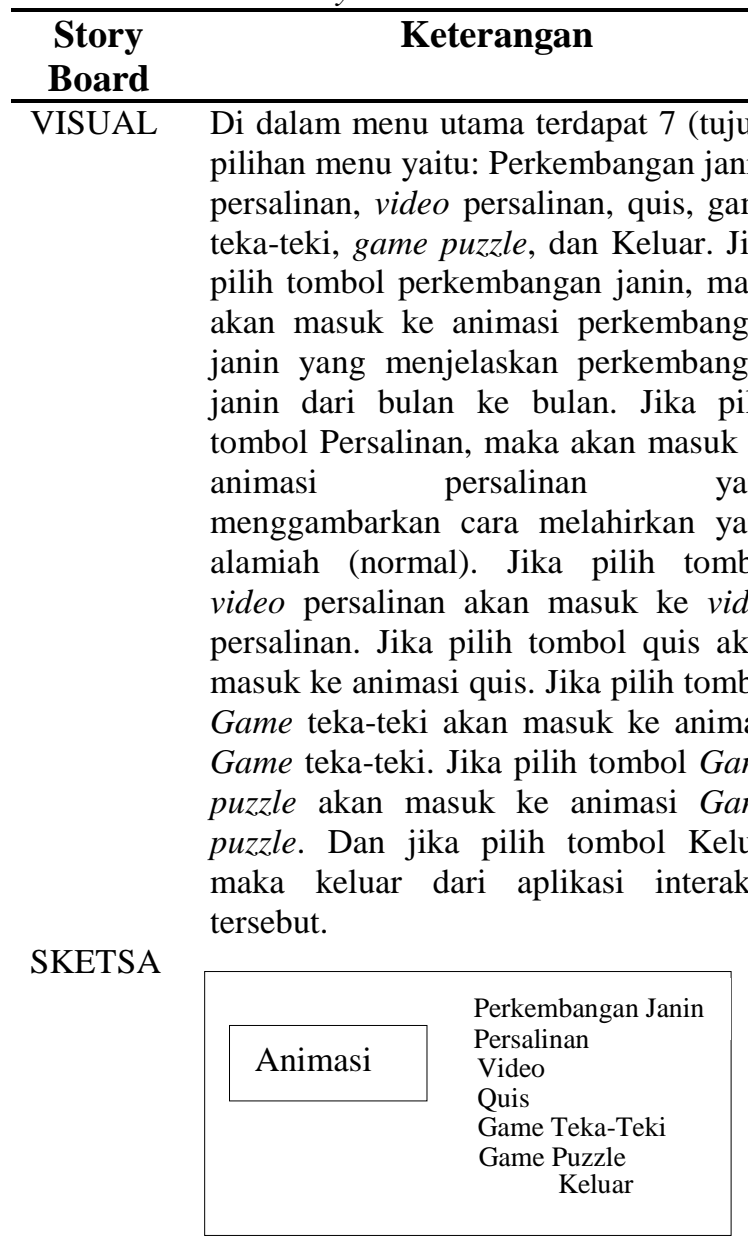

AUDIO

\section{User Interface Menu Opening}

Layar ini muncul pertama kali setelah user menjalankan game cover.exe.

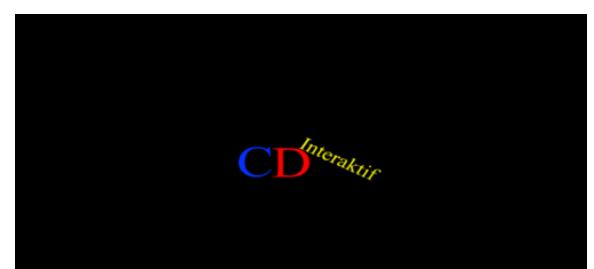

Gambar 1. Menu Opening

Kemudian muncul layar ini secara otomatis setelah menu opening, di dalam terdapat tombol Menu Utama dan Keluar. Tombol "menu utama" digunakan untuk masuk ke menu utama dan "keluar" digunakan untuk keluar dari aplikasi interaktif tersebut.

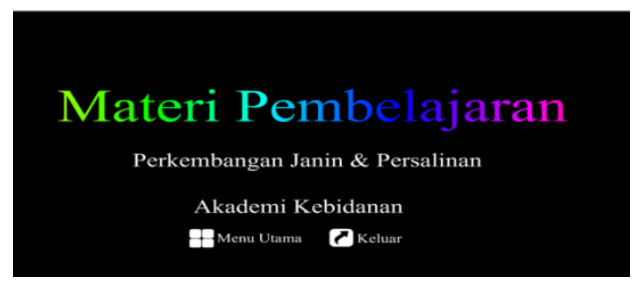

Gambar 2. Menu Opening

\section{User Interface Menu Utama}

Layar ini muncul setelah mengklik "tombol menu utama, maka akan muncul ke dalam animasi menu utama. Di dalam menu utama terdapat 7 tombol yaitu: Perkembangan Janin, Persalinan, Video Persalinan, Quis, Game Teka-Teki, Game Puzzle dan Keluar.

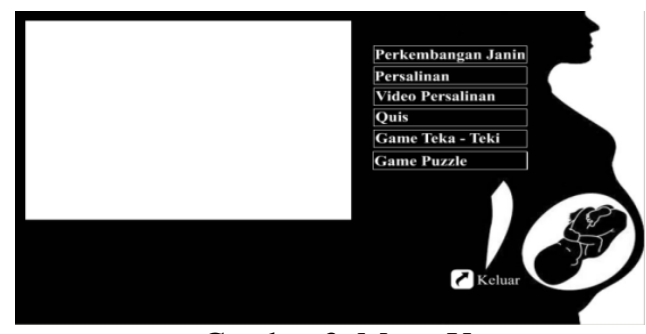

Gambar 3. Menu Utama

\section{Pengujian Sistem dengan Black Box}

Aplikasi interaktif yang telah dibuat, selanjutnya diuji melalui teknik pengujian perangkat lunak yang meliputi black box. Untuk contoh pengujian terhadap beberapa tingakatan dari aplikasi memberikan hasil sebagai berikut: 
Tabel 5. Pengujian Black Box

\begin{tabular}{|c|c|c|c|}
\hline $\begin{array}{l}\text { Input/ } \\
\text { Event }\end{array}$ & Proses & $\begin{array}{c}\text { Output } \\
\text { /Next } \\
\text { Stage }\end{array}$ & $\begin{array}{c}\text { Hasil } \\
\text { Pengu } \\
\text { jian }\end{array}$ \\
\hline $\begin{array}{l}\text { Tombol } \\
\text { Menu } \\
\text { Utama }\end{array}$ & $\begin{array}{l}\text { menu.onRelease = } \\
\text { function() \{ } \\
\text { loadMovieNum("m } \\
\text { aster load.swf", 0); } \\
\} ; \\
\text { exit.onRelease = } \\
\text { function() \{ } \\
\text { unloadMovieNum( } \\
\text { 1); } \\
\} ; \\
\text { menu.onRelease = } \\
\text { function() \{ } \\
\text { loadMovieNum("m } \\
\text { aster load.swf", 0); } \\
\} ; \\
\text { exit.onRelease = } \\
\text { function() \{ }\end{array}$ & $\begin{array}{l}\text { Menu } \\
\text { Utama }\end{array}$ & Sesuai \\
\hline & $\begin{array}{l}\text { unloadMovieNum( } \\
\text { 1); } \\
\text { \}; }\end{array}$ & & \\
\hline $\begin{array}{l}\text { Tombol } \\
\text { Keluar }\end{array}$ & $\begin{array}{l}\text { on (release) \{ } \\
\text { fscommand("quit"); } \\
\}\end{array}$ & Keluar & Sesuai \\
\hline
\end{tabular}

\section{KESIMPULAN}

Berdasarkan hasil perancangan tentang aplikasi materi pembelajaran $\mathrm{CD}$ Interaktif untuk perkembangan janin dan persalianan yang berbasis animasi yang telah dibuat maka dapat diambil kesimpulan sebagai berikut:
Perangkat lunak ini menyajikan banyak kemudahan dalam mempelajari materi-materi pelajaran sekolah khususnya yang memerlukan praktek; Perangkat lunak interaktif yang dibuat ini tidak harus menggantikan posisi media lain yang sudah ada, tetapi sebagai alat bantu atau pelengkap bagi media penyampaian/informasi yang telah ada sebelumnya; Dengan adanya perangkat lunak ini dapat membantu siswa dalam memahami materi yang sulit di mengerti karena perlunya visualisasi.

\section{DAFTAR PUSTAKA}

[1]. D.W. Samodra, V. Suhartono, S. Santosa. Multimedia Pembelajaran Reproduski Pada Manusia. Jurnal Teknik Informatika. 5. 2009.

[2]. G.M. McAndrews, S. Chadwick, R.E. Mullen, Nacta Journal. URL: http://proquest.com (Diskses 15 Desember 2010).

[3]. B. Iwan. 2010. Multimedia Digital Teori $+\quad$ Pengembangannya. Yogyakarta:ANDI.

[4]. F. Ibis. 2002. Macromedia Flash Animation \& Cartooning: A Creative Guide. McGraw-Hill: London.

[5]. I. Setiawan. 2006. Perancangan Software Embedded System Berbasis FSM. Semarang: Universitas Diponegoro

[6]. A.T. Hidayatullah. 2007. Secara Mudah Membuat Objek Web dengan Macromedia Flash Profesional 8. Surabaya: Indah Surabaya.

[7]. H. Hendratman. 2008. The Magic of Macromedia Director. Bandung:Informatika 